\title{
Penguatan budaya hukum masyarakat untuk menghasilkan kewarganegaraan transformatif
}

\author{
Iman Pasu Marganda Hadiarto Purba \\ Universitas Negeri Surabaya \\ imanpurba@unesa.ac.id
}

\begin{abstract}
Transformative citizenship becomes a crucial discourse to be realized both in civil and political life in order to achieve national state. Establishing transformative citizenship means shaping critical and active citizen on emergent issues as well as aware their role and function in political life. One of important things is their involvement in law system. According to Lawrence Friedman the element of system of law consists of structure of law, material of law and culture of law. Cultural law is the rarest element focused seriously by stakeholders in developing law. In diversity context of religion, race, local culture such as those in Indonesia, it is a challenging effort to develop national law. Therefore, it is important to enforce cultural law in order achieve the purpose of law.
\end{abstract}

\section{Keywords: Citizenship transformative, law system, cultural Law}

\section{Pendahuluan}

Salah satu persoalan bangsa saat ini adalah rendahnya budaya hukum warga negara. Ini terlihat dengan jelas melalui situasi-situasi yang saat ini marak terjadi di Indonesia. Peristiwa yang sempat viral di media massa dan media sosial tentang pembakaran seorang teknisi sampai mati setelah salat di masjid dan dituduh mencuri amplifier masjid salah satu contoh betapa masyarakat Indonesia masih banyak mengedepankan emosi dibandingkan akal, apalagi wibawa hukum. Masih banyak contoh kasus yang terjadi di republik ini yang semua itu terjadi karena rendahnya budaya hukum masyarakat. Sementara pengakuan bahwa Indonesia adalah negara hukum dapat dilihat pada Pasal 1 ayat 3 Undang-Undang Dasar Negara Republik Indonesia Tahun 1945.

Status sebagai negara hukum ini tentunya menjadi acuan untuk melakukan pembangunan hukum nasional. Setiap warga negara tentunya memiliki peran yang sangat besar di dalam menghidupi status sebagai negara hukum. Bagaimanapun setiap warga negara memiliki Identitas nasional yang itu tidak terlepas dari identitas bangsanya. Untuk melakukan pembangunan hukum nasional tentunya tidak terlepas dari sistem hukum yang terdiri dari beberapa unsur yang terkait satu sama lain untuk mencapai tujuan hukum itu sendiri. Keberadaan Indonesia yang sangat majemuk yang beragam suku, bahasa, budaya, dan agama tentunya akan mempengaruhi bagaimana proses pembangunan hukum nasional yang sedang diupayakan.

Teori sistem hukum Friedman (2009, p. 33) menyatakan ada tiga unsur pembentuk sistem hukum yakni substansi hukum (legal substance), struktur hukum (legal structure) dan budaya hukum (legal culture). Struktur hukum adalah komponen struktural atau organ yang bergerak di dalam suatu mekanisme, baik dalam membuat peraturan, maupun dalam menerapkan atau melaksanakan peraturan. Substansi hukum adalah produk dari struktur hukum, baik peraturan yang dibuat melalui mekanisme struktur formal atau peraturan yang lahir dari kebiasaan. Sedangkan budaya hukum adalah nilai, pemikiran, serta harapan atas kaidah 
atau norma dalam kehidupan sosial masyarakat. Ketiga unsur pembentuk sistem hukum ini memiliki keterkaitan satu sama lain dimana diantara ketiga unsur tersebut terharmonisasi di dalam proses pencapaian tujuan hukum itu sendiri. Penguatan budaya hukum nasional ini tentunya tidak terlepas dari norma-norma atau nilai-nilai dasar yang disepakati bersama sebagai bangsa dan negara yakni Pancasila dan Undang-Undang Dasar Negara Republik Indonesia Tahun 1945. Setiap warga negara di dalam sistem hukum tersebut dapat mengambil alih dalam subsistem budaya hukum.

Dalam praktik kehidupan bernegara, berbangsa dan bermasyarakat, secara mendasar (grounded dogmatic) dimensi kultur seyogianya mendahului dimensi lainnya, karena dalam dimensi budaya itu tersimpan seperangkat nilai (value system). Selanjutnya sistem nilai ini menjadi dasar perumusan kebijakan (policy) dan kemudian disusul dengan pembuatan hukum (law making) sebagai rambu-rambu yuridis dan code of conduct dalam kehidupan masyarakat sehari-hari, yang diharapkan akan mencerminkan nilai-nilai luhur yang dimiliki oleh bangsa yang bersangkutan. Dari ketiga unsur pembentuk sistem hukum menurut Friedman, kultur hukumlah (legal culture) yang mendahului dua unsur lainnya (Lubis, 2000). Penulis sepakat dengan pendapat ini karena sesungguhnya dalam tatanan kehidupan masyarakat tentunya sudah terdapat nilai-nilai yang secara natural terbentuk dan hidup di dalam proses interaksi sosial yang berlangsung. Mendahului dalam hal ini bukan berarti yang terpenting dari kedua unsur lainnya.

Jika suatu masyarakat diperhatikan, maka akan tampak walaupun sifat-sifat individu berbeda-beda, namun para warga keseluruhannya akan memberikan reaksi yang sama terhadap gejala-gejala tertentu. Dengan adanya reaksi yang sama itu maka mereka memiliki sikap yang umum sama. Hal-hal yang merupakan milik bersama tersebut dalam antropologi budaya dinamakan Kebudayaan. Ditarik dari pengertian yang demikian, maka budaya hukum merupakan salah satu bagian dari kebudayaan manusia yang demikian luas. Budaya hukum adalah tanggapan umum yang sama dari masyarakat tertentu terhadap gejala-gejala hukum. Tanggapan itu merupakan kesatuan pandangan terhadap nilai-nilai dan perilaku hukum. Jadi suatu budaya hukum menunjukkan tentang pola perilaku individu sebagai anggota masyarakat yang menggambarkan tanggapan (orientasi) yang sama terhadap kehidupan hukum yang dihayati masyarakat bersangkutan (Hadikusuma, 1986).

Masalah pembinaan kesadaran hukum erat kaitannya dengan berbagai faktor, khususnya sikap para pelaksana hukum artinya para penegak hukum memiliki peranan yang besar dalam membina pertumbuhan kesadaran masyarakat. Kesadaran hukum dalam konteks ini berarti kesadaran untuk bertindak sesuai dengan ketentuan hukum dan berfungsi sebagai jembatan yang menghubungkan antara peraturan hukum dengan tingkah laku anggota masyarakatnya berbicara mengenai pembangunan hukum tentunya dari keberadaan kehidupan masyarakat dimana hukum tersebut berlaku dan berubah sesuai dengan dinamika yang terjadi di dalam kehidupan bermasyarakat. Hingga saat ini masih ada kesenjangan antara hukum yang seharusnya (das sollen) dengan hukum yang senyatanya (das sein). Kesenjangan ini tentunya terjadi karena adanya 
ketidakharmonisan antara law in the books dengan law in action. Sejalan dengan itu, maka diperlukan upaya pembangunan hukum, yang sering diartikan sebagai penyelenggaraan perubahan tertentu terhadap masyarakat (law is a tool of social engineering), dan tentunya pembangunan yang diharapkan oleh hukum adalah perubahan masyarakat yang secara teratur, terkendali, efektif dan efisien.

Dapat diidentifikasi bahwa masalah pembangunan hukum nasional tidak hanya menyangkut materi hukum, struktur hukum tetapi juga masalah peningkatan kesadaran hukum masyarakat dan budaya hukum masyarakat. Malah peningkatan kesadaran hukum masyarakat ini seharusnya mendahului unsur pembentuk sistem hukum lainnya. Dalam melaksanakan pembinaan hukum ke depan, justru yang perlu mendapat perhatian utama adalah masalah kesadaran hukum masyarakat dan budaya hukum masyarakat ini. Hal ini disebabkan karena masyarakat Indonesia merupakan masyarakat majemuk atau pluralistik, yang mencakup pelbagai kesadaran baik yang bersifat pribadi maupun kelompok. Dengan demikian terdapat kesadaran hukum yang tidak tunggal atau seragam, meski harus diakui bahwa atas dasar studi perbandingan, terdapat bermacammacam persamaan di dalam masyarakat majemuk tersebut. Oleh karenanya timbul permasalahan bagaimana penguatan budaya hukum masyarakat dalam upaya menghasilkan warga negara yang transformatif.

\section{Pembahasan}

Implikasi peranan hukum dalam pergaulan hidup manusia, maka hukum harus peka terhadap perkembangan masyarakat yang serba berubah, dan harus mampu menyesuaikan diri dengan berbagai keadaan yang juga berubah-ubah. Oleh sebab itu, tidak perlu ada kontradiksi antara pembaharuan hukum (tertulis) dengan nilai-nilai dan aspirasi yang hidup dalam masyarakat. Dengan demikian, pemikiran terhadap peranan hukum sebagai alat perubahan dan pembangunan masyarakat, sebagaimana dikemukakan oleh Pound, perlu ditempatkan pada persepsi yang disepakati bersama untuk memahami sifat, hakikat dan konsekuensi diterimanya suatu konsepsi. Dengan demikian selalu terdapat gejala bahwa antara hukum dan perilaku sosial terdapat suatu jarak perbedaan yang sangat mencolok. Apabila hal ini terjadi, maka akan timbul ketegangan yang semestinya harus segera disesuaikan supaya tidak menimbulkan ketegangan yang berkelanjutan, tetapi usaha ke arah ini selalu terlambat dilakukan (Manan, 2006).

Teori Pound mengenai kepentingankepentingan sosial merupakan sebuah usaha yang lebih eksplisit untuk mengembangkan suatu model hukum responsif yang mana dalam perspektif ini, hukum yang baik seharusnya memberikan sesuatu yang lebih daripada sekadar prosedur hukum. Hukum tersebut harus kompeten dan juga adil, hukum seharusnya mampu mengenali keinginan publik dan punya komitmen terhadap tercapainya keadilan substantif (Nonet \& Selznick, 2013, pp. 59-60). Setiap warga negara seharusnya dapat berpikir kritis untuk mengidentifikasi kepentingan-kepentingan sosial ini dan melibatkan diri di dalam pencapaian kepentingan-kepentingan tersebut.

Untuk dapatnya hukum berfungsi sebagai pengayom masyarakat, maka diperlukan faktor pendukung yaitu fasilitas yang diharapkan akan mendukung pelaksanaan norma hukum yang berlaku dalam kehidupan masyarakat. Selain dari itu, berfungsinya 
hukum sangat tergantung pada hubungan yang serasi antara hukum itu sendiri (perangkat aturan hukum, aparat penegak hukum dan kesadaran masyarakat. Kekurangan salah satu dari unsur ini akan mengakibatkan seluruh sistem hukum akan berjalan pincang. Berdasarkan pemahaman terhadap sistem hukum nasional yang menyangkut adanya empat komponen atau sub sistem, yakni: 1 . budaya hukum, 2. materi hukum, 3. lembaga, organisasi, aparatur dan mekanisme hukum, serta 4. prasarana dan sarana hukum. Maka salah satu yang sangat urgen dalam membangun kultur dalam rangka menyikapi perubahan hukum adalah pembangunan materi hukum. Untuk mewujudkan hal tersebut, maka diperlukan dua pandangan atau pemikiran yang berperan dalam sistem hukum yang akan dibina secara terpadu, yakni aliran yang meninjau hukum secara yuridis dogmatis, yang cenderung mempertahankan nilai-nilai moral dan kultural Indonesia dalam pembinaan hukum itu dan aliran yang meninjau hukum dari segi dimensi sosial yang cenderung mengutamakan pembinaan sistem hukum yang mampu menjawab tuntutan pembangunan dan modernisasi (Lubis, 2002). Apa yang dimaksud budaya hukum adalah keseluruhan faktor yang menentukan bagaimana sistem hukum memperoleh tempatnya yang logis dalam kerangka budaya milik masyarakat umum. Budaya hukum bukanlah apa yang secara kasar disebut opini publik para antropolog, budaya itu tidak sekadar berarti himpunan fragmen-fragmen tingkah laku (pemikiran) yang saling terlepas, istilah budaya diartikan sebagai keseluruhan nilai sosial yang berhubungan dengan hukum (Soekanto, 1977, p. 2) . Budaya hukum jika diartikan secara gramatikal maka akan menghasilkan banyak pandangan, walaupun sebenarnya pandangan tersebut bebas. Namun kiranya dalam pendidikan hukum ke depan, budaya hukum haruslah memiliki batasanbatasan dalam pengertiannya agar tidak menimbulkan interpretasi di dalam masyarakat. Sebagaimana diungkapkan Asshiddiqie (2005, p. 26) bahwa pembudayaan, pemasyarakatan dan pendidikan hukum (law socialization and law education) dalam arti luas sering tidak dianggap penting, padahal tanpa didukung oleh kesadaran, pengetahuan dan pemahaman oleh para subjek hukum dalam masyarakat, akan sangat sulit suatu norma hukum dapat diterapkan tegak dan ditaati. Karena itu, agenda pembudayaan, pemasyarakatan dan pendidikan hukum ini perlu dikembangkan tersendiri dalam rangka mewujudkan ide negara hukum di masa depan.

Hukum yang dibuat pada akhirnya sangat ditentukan oleh budaya hukum yang berupa nilai, pandangan serta sikap dari masyarakat yang bersangkutan. Jika budaya hukum diabaikan, maka dapat dipastikan akan terjadi kegagalan dari sistem hukum modern yang ditandai dengan munculnya berbagai gejala seperti: kekeliruan informasi mengenai isi peraturan hukum yang ingin disampaikan kepada masyarakat, muncul perbedaan antara apa yang dikehendaki oleh undang-undang dengan praktik yang dijalankan oleh masyarakat. Masyarakat lebih memilih untuk tetap bertingkah laku sesuai dengan apa yang telah menjadi nilai-nilai dan pandangan dalam kehidupan mereka. Gambaran mengenai budaya hukum dalam unsur-unsur sistem hukum adalah struktur hukum diibaratkan sebagai mesin yang menghasilkan sesuatu, substansi hukum diibaratkan produk yang di hasilkan oleh mesin, dan budaya hukum merupakan apa saja atau siapa saja yang memutuskan untuk menjalankan mesin 
serta membatasi penggunaan mesin (Makmur, 2015). Sehingga urgensi penguatan budaya hukum ini sudah menjadi kebutuhan yang tidak terelakkan lagi. Oleh karena itu pengembangan budaya hukum harus dilakukan melalui strategi pengembangan yang terarah dan terukur melalui perumusan kebijakan, strategi pembudayaan hukum dan upaya pengembangan budaya hukum (Jawardi, 2016). Penguatan budaya hukum ini salah satu bagian dari peran di dalam melahirkan kewarganegaraan transformatif di Indonesia.

Menurut tujuan kebijakan strategis, yang penting adalah sejauh mana lembaga perumus kebijakan dan penyusun peraturan hukum secara konsisten tetap mengacu kepada sistem nilai yang filosofis itu agar setiap garis kebijakan dan aturan hukum yang tercipta dinilai akomodatif dan responsif terhadap aspirasi masyarakat, secara adil dengan perhatian yang merata. Kearifan politis dengan pendekatan kultural seperti ini menjadi tuntutan konstitusional seluruh rakyat Indonesia yang struktur sosialnya penuh keanekaragaman, pluralis dan heterogen, beragam-ragam sub etnis, agama, adat istiadat dan unsur-unsur kulturalnya (Lubis, 2000). Jika hal ini terlaksana maka sebenarnya sedang tercipta harmonisasi antara legal substance dengan legal structure. Namun satu hal yang terpenting adalah bagaimana aturan-aturan tersebut dapat hidup, bernilai dan dijadikan pedoman dalam kehidupan bermasyarakat. Sehingga dipandang penting untuk meningkatkan budaya hukum masyarakat. Kendatipun aturan-aturan tersebut bersifat akomodatif dan responsif namun masyarakat tidak mengetahui dan menyadarinya maka sesungguhnya aturan-aturan tersebut hanya sebatas aturan-aturan formal yang tidak berdaya guna dan berdaya laku. Jika demikian kebijakan yang dilakukan maka akan ada harmonisasi antara legal structure, legal substance dan legal culture.

Salah satu upaya yang dilakukan dalam meningkatkan budaya hukum dan kesadaran hukum adalah melalui pendidikan dan sosialisasi berbagai peraturan perundangundangan dalam rangka mematuhi dan mentaati hukum serta penegakan supremasi hukum (Jawardi, 2016). Salah satu upaya yang dilakukan dalam meningkatkan budaya hukum dan kesadaran hukum adalah melalui pendidikan dan sosialisasi berbagai peraturan perundang-undangan dalam rangka mematuhi dan mentaati hukum serta penegakan supremasi hukum. Salah satu cara yang efektif adalah dengan melakukan penyuluhan hukum.

Penyuluhan Hukum adalah salah satu kegiatan penyebarluasan informasi dan pemahaman terhadap norma hukum dan peraturan perundang-undangan yang berlaku guna mewujudkan dan mengembangkan kesadaran hukum masyarakat sehingga tercipta budaya hukum dalam bentuk tertib dan taat atau patuh terhadap norma hukum dan peraturan perundang-undangan yang berlaku demi tegaknya supremasi hukum. Sampai saat ini penyuluhan hukum telah dilaksanakan dengan berbagai cara dan metode. Secara garis besar metode penyuluhan hukum dibagi menjadi dua, yaitu penyuluhan hukum langsung dan penyuluhan hukum tidak langsung. Metode Penyuluhan Hukum adalah cara penyampaian informasi hukum dari penyuluh hukum kepada sasaran penyuluhan hukum. Penyuluhan hukum langsung dilakukan dengan cara bertatap muka secara langsung antara penyuluh dan yang disuluh. Penyuluhan hukum tidak langsung merupakan penyuluhan hukum yang 
dilakukan melalui media cetak dan media elektronik. Penyuluhan Hukum melalui media elektronik salah satunya adalah melalui televisi, baik TVRI maupun Televisi swasta (Jawardi, 2016).

Hadirnya Fungsional penyuluh hukum di jajaran Kementerian Hukum dan HAM (Kemenkumham) diibaratkan seperti datangnya hujan di musim kemarau artinya ke depan penyuluh hukum di Kemenkumham ini sangat dibutuhkan untuk memberikan informasi hukum kepada masyarakat yang buta dengan hukum. Walaupun dirasakan agak terlambat kehadiran penyuluh hukum ini, tetapi patut disyukuri bahwa pada awal tahun sudah hadir lebih kurang 210 penyuluh hukum dari berbagai tingkatan (penyuluh ahli pertama, ahli muda, ahli madya dan ahli utama), yang telah dilantik oleh menteri hukum dan HAM Yasonna H. Laoly tanggal 21 Desember 2016. Semoga fungsional penyuluh hukum dapat mendarmabaktikan pengabdiannya kepada masyarakat untuk melakukan penyuluhan hukum dan mendapat tempat yang baik di lingkungan Kementerian Hukum dan HAM RI. Kalau dibandingkan dengan jumlah penduduk dan luasnya geografis Indonesia tentu jumlah fungsional penyuluh hukum yang ada saat ini belum mencukupi. Jumlah yang ideal untuk penyuluh hukum diperkirakan sebanyak 85.000 penyuluh hukum, dengan asumsi sama dengan jumlah desa di Indonesia. Jadi untuk 1 (satu) desa dibutuhkan 1 (satu) penyuluh hukum (Jawardi, 2016). Kendatipun pemerintah sudah memberi perhatian terhadap penguatan budaya hukum masyarakat ini dengan menghadirkan tenaga fungsional Penyuluh Hukum di Kementerian Hukum dan Hak Asasi Manusia Republik Indonesia, namun dari segi jumlah tentunya tidak akan memberikan pengaruh yang sangat signifikan. Berbeda halnya dengan keberadaan Penyuluh Pertanian yang dari segi jumlah sangat signifikan perbedaannya dengan Penyuluh Hukum yakni sejumlah 12.007 Penyuluh Pertanian Pegawai Negeri Sipil, mengingat Indonesia adalah juga negara agraris (Julianto, 2016). Sebagai negara hukum sudah seharusnya pemerintah dapat memberi perhatian dalam hal menambah jumlah penyuluh hukum ini demi meningkatnya kesadaran dan budaya hukum masyarakat yang baik.

Beberapa hal yang perlu dilakukan dalam rangka mendukung upaya pembudayaan dan kecerdasan hukum masyarakat, adalah sebagai berikut:

1. Upaya pembudayaan hukum harus dilakukan dengan metode yang tepat dan efektif, dengan memanfaatkan berbagai media dan infrastruktur serta lembagalembaga yang hidup dan tumbuh di masyarakat.

2. Sosialisasi berbagai materi hukum, perlu terus diupayakan agar setiap perkembangan terbaru mengenai perundang-undangan diketahui dan dipahami oleh masyarakat. Dengan demikian, ketersediaan dan kemudahan akses terhadap informasi materi hukum secara mudah, menjadi bagian penting dari upaya pembudayaan hukum masyarakat.

3. Budaya hukum masyarakat harus dibangun paralel dengan peningkatan profesionalisme aparat penegak hukum dan birokrasi. Karena profesionalisme ini akan sangat berpengaruh terhadap kepercayaan masyarakat terhadap hukum itu sendiri.

4. Perlu dilakukan pola dan program pembudayaan hukum secara terpadu, terencana dan didasarkan kepada faktafakta permasalahan hukum yang terjadi. Dengan demikian, keberadaan tenaga fungsional penyuluh hukum, perlu segera direalisasikan. 
5. Pembudayaan hukum harus dilakukan sejak usia dini dan dimulai dari rumah tangga sebagai miniatur terkecil negara hukum, untuk mencapai masyarakat berbudaya hukum saat ini dan masa depan (Jawardi, 2016).

Prinsip-prinsip yang mendukung pembudayaan hukum dan kecerdasan hukum masyarakat tersebut diatas akan menghasilkan masyarakat yang berbudaya hukum atau cerdas hukum (Susilawati, 2008). Ciri-ciri masyarakat cerdas hukum adalah masyarakat yang memahami hukum secara komprehensif yang terkait dengan hak dan kewajibannya, mengetahui kebolehan-kebolehan dan larangan-larangan serta memahami keuntungan dan risiko apa saja yang akan dialami terkait perbuatan hukum yang dilakukannya, teliti dan cermat dalam mengambil langkah-langkah dan tindakantindakan hukum serta mampu menjauhi segala perbuatan yang dapat menimbulkan pelanggaran hukum, mampu menghindari perbuatan yang menjurus kepada pelanggaran hukum. Unsur lain kecerdasan hukum masyarakat adalah kemampuan untuk berperan serta dalam upaya mewujudkan negara hukum yang demokratis, melalui kontribusi pemikiran dalam rangka pembangunan hukum nasional, sehingga hukum yang dibuat benar-benar dapat mencerminkan nilai-nilai filosofis, sosiologis dan yuridis.

\section{Simpulan}

Berdasarkan uraian yang telah dikemukakan dalam bagian sebelumnya, dapat disusun beberapa kesimpulan sebagai berikut:

1. Hingga saat ini masih ada kesenjangan antara hukum yang seharusnya (das sollen) dengan hukum yang senyatanya (das sein). Kesenjangan ini tentunya terjadi karena adanya ketidakharmonisan antara law in the books dengan law in action. Sejalan dengan itu, maka diperlukan upaya pembangunan hukum, yang sering diartikan sebagai penyelenggaraan perubahan tertentu terhadap masyarakat (law is a tool of social engineering), dan tentunya pembangunan yang diharapkan oleh hukum adalah perubahan masyarakat yang secara teratur, terkendali, efektif dan efisien. Hal ini merupakan bagian dari upaya mewujudkan kewarganegaraan transformatif.

2. Pembangunan hukum nasional dapat diartikan sebagai upaya untuk melakukan perubahan di bidang hukum atau tatanan hukum yang terencana untuk menghasilkan hukum yang berdaya laku tinggi karena sesuai dengan budaya hukum masyarakat dimana akan tercipta sistem hukum yang sesuai dengan nilainilai budaya bangsa yakni Pancasila dan UUD 1945 sebagai dasar negara dan ideology bangsa. Nilai-nilai budaya yang dimaksudkan adalah nilai-nilai yang termaktub di dalam Pancasila. Sehinga tidak berlebihan jika yang dimaksudkan adalah budaya hukum Pancasila. Warga negara transformatif memiliki budaya hukum Pancasila.

3. Pembangunan hukum itu secara sistemis menyangkut (a) materi hukum dan prosedur-prosedurnya, (b) institusi, termasuk aparat yang terlibat di dalamnya, mekanisme kerja institusi hukum, serta sarana dan prasarana penunjang yang diperlukan untuk itu, serta menyangkut (c) kesadaran hukum dan budaya hukum masyarakat yang menjadi subjek hukum yang bersangkutan. Di dalam agenda pembangunan hukum tidak terlepas dari 
pentingnya membangun kesadaran dan budaya hukum masyarakat.

4. Di dalam RPJP pembangunan hukum diarahkan pada perwujudan masyarakat yang mempunyai kesadaran dan budaya hukum yang tinggi dalam rangka mewujudkan negara hukum serta penciptaan kehidupan masyarakat yang adil dan demokratis. Masalah kesadaran hukum adalah salah satu bagian dari permasalahan pembangunan hukum di Indonesia.

5. Hadirnya Fungsional penyuluh hukum di jajaran Kementerian Hukum dan HAM diibaratkan seperti datangnya hujan di musim kemarau artinya ke depan penyuluh hukum di Kementerian Hukum dan HAM ini sangat dibutuhkan untuk memberikan informasi hukum kepada masyarakat yang buta dengan hukum. Sebagai negara hukum sudah seharusnya pemerintah dapat memberi perhatian dalam hal menambah jumlah penyuluh hukum ini demi meningkatnya kesadaran dan budaya hukum masyarakat yang baik.

6. Ciri-ciri masyarakat cerdas hukum adalah masyarakat yang memahami hukum secara komprehensif yang terkait dengan hak dan kewajibannya, mengetahui kebolehan-kebolehan dan laranganlarangan serta memahami keuntungan dan risiko apa saja yang akan dialami terkait perbuatan hukum yang dilakukannya, teliti dan cermat dalam mengambil langkah-langkah dan tindakan-tindakan hukum serta mampu menjauhi segala perbuatan yang dapat menimbulkan pelanggaran hukum, mampu menghindari perbuatan yang menjurus kepada pelanggaran hukum

\section{Daftar Pustaka}

Asshiddiqie, J. (2005). Implikasi perubahan UUD 1945 terhadap pembangunan hukum nasional. Jakarta: Mahkamah Konstitusi Republik Indonesia.

Friedman, L. M. (2009). Sistem hukum perspektif ilmu sosial. (M. Khozin, Trans.). Bandung: Nusa Media.

Hadikusuma, H. (1986). Antropologi hukum Indonesia. Bandung: Alumni.

Jawardi. (2016). Strategi pengembangan budaya hukum. Jurnal Penelitian Hukum De Jure, 16(1), 77-93.

Julianto, P. A. (2016). Kementan: Indonesia kekurangan jumlah penyuluh pertanian.

Lubis, M. S. (2000). Politik dan hukum di era reformasi. Bandung: Mandar Maju.

Lubis, M. S. (2002). Sistem nasional. Bandung: Mandar Maju.

Makmur, S. (2015). Budaya hukum dalam masyarakat multikultural. SALAM: Jurnal Sosial Dan Budaya Syari, 2(2), 1-34.

Manan, A. (2006). Aspek-aspek pengubah hukum. Jakarta: Kencana Prenada Media.

Nonet, P., \& Selznick, P. (2013). Hukum responsif pilihan di masa transisi. Jakarta: Perkumpulan Untuk Pembaharuan Hukum Berbasis Masyarakat dan Ekologis (Hu Ma).

Soekanto, S. (1977). Hukum dan masyarakat. Surabaya: Universitas Airlangga.

Susilawati, S. (2008). Kebijakan implementasi penyuluhan dalam rangka tahun peningkatan budaya hukum nasional. Jakarta: BPHN. 